\title{
UNDERSTANDING VITAMIN $B_{12}$
}

\author{
Hanna M. Hüpsch-Marzec', Roman Pawlak', Dariusz Skaba' ${ }^{1}$ \\ 'Department of Periodontal and Oral Mucosa Diseases, School of Medicine with the Division of Dentistry in Zabrze, Medical University of Silesia, Poland \\ ${ }^{2}$ Department of Nutrition Science, East Carolina University, United States
}

\begin{abstract}
Dentists often act as primary care physicians. If they are able to identify symptoms of vitamin $\mathrm{B}_{12}$ deficiency, dentists can identify the problem at the early stage of the pathology. They can make appropriate referrals to specialists who can make a diagnosis and recommend treatment. Effective treatment may be possible at the stage before neurological symptoms occur, preventing irreversible changes to the body. Vitamin $B_{12}$ (cobalamin) plays an essential role in many metabolic processes, including biosynthesis of nucleic acids. The clinical manifestations of vitamin $\mathrm{B}_{12}$ deficiency are highly polymorphic and depend on many factors. This review presents fundamental information about the structure of vitamin $\mathrm{B}_{12}$, its dietary sources, up-to-date understanding of its role in the human body and the most important consequences of its deficiency, including manifestations within the mucous membrane of the oral cavity. Due to the fact that a large percentage of adults and elderly patients have an undiagnosed vitamin $\mathrm{B}_{12}$ deficiency it is prudent to screen for vitamin $B_{12}$ status. Methylmalonic acid and/or holotranscobalamin II (holoTCII) have been proposed to be the most sensitive assessment methods. Among high risk groups (e.g. the elderly, vegetarians, people with gastrointestinal health conditions), screening should be recommended at each annual examination.
\end{abstract}

KEY WORDS: oral cavity, deficiency, causes, cobalamin, vitamin $B_{12}$.

J Stoma 2019; 72, 4: 184-189

DOI: https://doi.org/10.5114/jos.2019.91237

\section{INTRODUCTION}

Vitamin $\mathrm{B}_{12}$ (cobalamin, $\mathrm{B}_{12}$ ) belongs to the group of water-soluble vitamins. It is essential in several metabolic processes in the body. For example, it plays an indispensable role in ensuring the proper functioning of the nervous and hematopoietic systems.

\section{THE STRUCTURE OF VITAMIN $B_{12}$}

$\mathrm{B}_{12}$ encompasses several chemical compounds with corrin rings along with a cobalt ion as their common features. These compounds include cyanocobalamin, hydro- xocobalamin, methylcobalamin, aquacobalamin, and deoxyadenosylcobalamin [15]. The central part of the molecule consists of four reduced and frequently substituted pyrrole rings which surround a single cobalt atom [15]. The bulk of circulating cobalamin in the blood is methylcobalamin; other forms include 5-deoxyadenosylcobalamin and hydroxocobalamin.

In addition to the metabolically active $B_{12}$, there are so-called "pseudocobalamins," which constitute analog forms that retain activity in bacterial cells but do not exhibit biological function in humans [26]. Those forms are present in food products of plant origin (e.g. fermented soy products) [34].

\section{JOURNAL OF} STOMATOLOGY CZASOPISMO STOMATOLOGICZNE

AdDRESS FOR CORRESPONDENCE: Prof. Roman Pawlak, Department of Nutrition Science, East Carolina University, Rivers West, NC 27858, Greenville, United States, e-mail: pawlakr@ecu.edu 


\section{SOURCES OF VITAMIN $B_{12}$}

The human body cannot synthesize cobalamin so it must be ingested with foods. Synthesis of $B_{12}$ is exclusive to prokaryotes, such as the bacteria that inhabit the intestinal tract of humans and animals and certain microorganisms found in soil and water [46]. The source of $B_{12}$ for humans is primarily meat and animal products $[15$, 34]. The body can store $B_{12}$ especially in the liver and the kidneys.

$\mathrm{B}_{12}$ is not found in any food products of plant origin [34]. For pharmaceutical purposes, $B_{12}$ is isolated as a byproduct derived from the following microorganisms: Propionibacterium freudenreichii, Propionibacterium shermanii and Pseudomonas denitrificans [51].

\section{METABOLISM OF COBALAMIN}

Cyanocobalamin, a compound composed of cyanide and cobalamin, is the most common form of $\mathrm{B}_{12}$ found in many foods that were fortified with this vitamin and in $\mathrm{B}_{12}$-containing dietary supplements. It is an inactive form of $B_{12}$ and thus the cyanide must be split off from cobalamin in enzymatic processes in order to create the active forms. The metabolism of cobalamin involves many biochemical processes. Disorders in the course of any of them may lead to $B_{12}$ deficiency.

\section{ABSORPTION AND TRANSPORT}

The process of absorption begins in the oral cavity. Protein-bound $\mathrm{B}_{12}$, along with R-proteins secreted with saliva, enters the stomach [34]. In the acidic environment of the stomach in the presence of hydrochloric acid and pepsin, $B_{12}$ is separated from the protein and is subsequently attaching to the intrinsic factor (IF) creating $\mathrm{B}_{12}$-IF complexes. $\mathrm{B}_{12}$-IF complexes are then absorbed in the ileum. After being picked up by transcobalamin II, it enters the portal system $[15,34]$.

$\mathrm{B}_{12}$ in serum is bound to carrier proteins: transcobalamin I (approximately $80-90 \%$ of the total), transcobalamin II (0-20\%) and smaller amounts in transcobalamin III. Despite transcobalamin II representing such a small fraction, it plays a critical role in human health as it is the only protein carrier that is able to provide cobalamin to all cells in the body $[20,33]$.

Most $B_{12}$ is stored in the liver [15]. Only a small amount of the $\mathrm{B}_{12}$ supplied with food is absorbed ( $10-20 \%)$. The remainder is excreted with feces.

\section{FUNCTION OF VITAMIN B}

$\mathrm{B}_{12}$ plays an essential role in many metabolic vital processes, including biosynthesis of nucleic acids. Its role is closely linked with the role of folic acid. Supplying adequate amounts of $B_{12}$ is especially important during periods of cellular division and differentiation. Tissues that undergo fast turnover, such as blood cells, nerve tissue, respiratory and gastrointestinal tracts and skin, also need a steady supply of this nutrient.

Metabolically active methylcobalamin is a cofactor in the conversion of homocysteine (Hcy) to methionine [34]. Abnormal metabolism of folate, disorders related to DNA synthesis, and synthesis of megaloblastic cells in the hematopoietic system may result if this conversion is impaired [14].

Another active form of vitamin $B_{12}$, adenosylcobalamin, is responsible for the conversion of methylmalonyl-CoA to succinyl-CoA [34]. This form is involved in the metabolism of fats, carbohydrates, and protein. A deficiency of this form results in fatty acids with too few carbon atoms entering into lipid nerve cells. Consequently this disorder may result in neurological symptoms [47].

$\mathrm{B}_{12}$ is a donor of a methyl group in the process of protein methylation in the central nervous system where myelin sheaths are formed. It is involved in the maturation of red and white blood cell precursors as well as in the synthesis of hemoglobin [27]. $B_{12}$ is required to regulate the synthesis of cytokines such as tumor necrosis factor (TNF- $\alpha$ ), interleukin 6 (IL-6), nerve growth factor (NGF), and epidermal growth factor (EGF) in the nervous system [30-38, 40].

\section{DIETARY REFERENCE INTAKES}

The dietary recommendations for $\mathrm{B}_{12}$ differ from country to country [34]. For example, in the United States, the Institute of Medicine recommended intake of $2.4 \mu \mathrm{g} /$ day for non-pregnant adults, 2.6 for pregnant women, and 2.8 for lactating mothers [22]. The European Food Safety Authority has recommended a higher intake $-4.0 \mu \mathrm{g} /$ day for adults, $4.5 \mu \mathrm{g} /$ day for pregnant and $5.0 \mu \mathrm{g} /$ day for lactating women $[15,41]$.

\section{CAUSES OF VITAMIN B ${ }_{12}$ DEFICIENCY}

$\mathrm{B}_{12}$ deficiency is widespread $[1,34]$. The two main reasons for deficiency to develop include insufficient intake and malabsorption. Specific symptoms of $\mathrm{B}_{12}$ deficiency are listed in Table 1.

\section{EPIDEMIOLOGY OF COBALAMIN DEFICIENCY}

$\mathrm{B}_{12}$ deficiency can occur at any age [50]. In infancy and childhood, $\mathrm{B}_{12}$ deficiency complications (e.g. macrocytic anemia, neurological complications) occur mainly among those fed vegan and sometimes vegetarian diets and among offspring of women with an MTHFR gene defect [13]. $B_{12}$ deficiency has been reported in children 
TABLE 1. Causes of vitamin $B_{12}$ deficiency

\begin{tabular}{|c|c|}
\hline Causes of deficiency & Populations at risk \\
\hline Insufficient dietary intake of vitamin $\mathrm{B}_{12}$ & $\begin{array}{l}\text { Habitual low intake of meat and animal products (e.g. vegetarian and vegan diets, alcoholism, } \\
\text { patients with bulimia or anorexia nervosa) }\end{array}$ \\
\hline Malabsorption & $\begin{array}{l}\text { Insufficient secretion of intrinsic factor (IF), including congenital IF deficiency } \\
\text { Addison-Biermer anemia (presence of antibodies against parietal cells and IF and type A atrophic gastritis) } \\
\text { Total or partial gastrectomy (resection of the stomach) } \\
\text { Helicobacter pylori infection (as a factor damaging the gastric mucosa) } \\
\text { Use of prescription drugs (taking } \mathrm{H}_{2} \text {-receptor antagonists, proton pump inhibitors, metformin, colchicine, } \\
\text { cholestyramine, chronic use of anticonvulsants or antibiotics) } \\
\text { Achlorhydria (type B atrophic gastritis, bacterial flora overgrowth) } \\
\text { Chronic pancreatitis } \\
\text { Diseases of the ileum (e.g. Celiac disease, Crohn's disease, small bowel resection) } \\
\text { Sjögren's syndrome } \\
\text { HIV infection } \\
\text { Age-related Gl atrophies } \\
\text { Malnutrition (secondary to chronic alcoholism, associated with poverty and homelessness) } \\
\text { Decrease absorption of vitamin B }{ }_{12} \text { related to broad tapeworm infection, bacterial proliferation } \\
\text { (blind loop syndrome, small intestinal stenosis, presence of multiple diverticula) } \\
\text { Idiopathic causes }\end{array}$ \\
\hline
\end{tabular}

with autism who have been fed a diet that lacked variety and excluded meats and products of animal origin [36]. In the absence of other autoimmune and gastrological disorders, congenital inability to secrete IF is described as a form of Addison-Biermer disease in childhood [35]. Imerslund-Najman-Gräsbeck syndrome is a very rare genetic disorder associated with malabsorption of the IF- $B_{12}$ complex in the small intestine [6]. Crohn's disease, celiac disease, giardiasis and broad tapeworm infection are common causes of cobalamin deficiency in children [52].

Studies have shown that in industrialized countries cobalamin deficiency occurs in approximately 5-60\% of studied samples, depending on the definition of deficiency [2]. The prevalence of deficiency is higher among the elderly populations ( $30 \%$ to $40 \%$ ), especially among those who are not well nourished and among institutionalized individuals.

In a study conducted in Poland, latent deficiency was found in $6.8 \%$ of hospitalized patients between the years 1999-2000 [23]. In population studies in Finland, 32\% of the examined individuals had borderline deficiency [28]. In the United Kingdom, approximately $20 \%$ of people over 65 years old suffer from cobalamin deficiency [9].

\section{CLINICAL MANIFESTATIONS OF VITAMIN $B_{12}$ DEFICIENCY}

The clinical manifestations of $\mathrm{B}_{12}$ deficiency is highly polymorphic and depends on many factors (e.g. the degree of induced anemia and the pace of its development) [10]. Cobalamin deficiency gradually leads to pancytopenia, disorders of the digestive system, nervous system structural abnormalities and skin lesions [39]. In less severe cases, it is only manifested with individual symptoms (e.g. increasing fatigue, orthostatic hypotension, atrophy of the tongue or macrocytosis). In more severe cases, symptoms appear more complex, and may include degenerative changes in the spinal cord, hemolytic anemia, and pancytopenia [37, 39]. Neurological symptoms frequently precede hematological abnormalities $[35,39]$.

\section{SYMPTOMS IN THE ORAL CAVITY AND OTHER PARTS OF THE GASTROINTESTINAL TRACT}

Changes in the oral mucosa associated with cobalamin deficiency occur in approximately $50-60 \%$ of patients [18-37]. They may be the only symptoms of deficiency without hematological symptoms and may precede many systemic health problems $[12,16]$. It is believed that specific clinical manifestations of the tongue in patients with $B_{12}$ deficiency can guide physicians to make a correct diagnosis $[47,48]$. In a clinical study of the oral cavity, generalized atrophy of epithelial mucosa and inflammation can be observed. As a result of chronic inflammation, structural changes of epithelial cells develop, and abnormal keratinization causes disappearance of tongue warts, resulting in its smooth appearance. The dorsal surface and the edges become sensitive to thermal, chemical and mechanical stimuli, gradually making it difficult to talk and chew food. Erythematous spots may appear on the buccal mucosa and on edges of the dorsal surface of the tongue [37]. The socalled "Hunter's tongue" manifests as a shiny, lacquered tongue that assumes a "beefy" red color [17]. However, there is no evidence to suggest that the size of the oral "beefy red" lesion correlates with the severity of $\mathrm{B}_{12}$ deficiency [49]. In addition to the spots, red streaks that 
may be linear, U- or V-shaped may appear with the arms pointing toward the base of the tongue [49]. Warts within them are swollen and painful. The erythematous changes in the mouth described above may be confused with erythematous candidiasis or geographical tongue, among others. Although they seem similar, they are described as diffuse and confluent erythema mainly on the lingual dorsum, presenting as a red, depapillated area or on the denture-bearing mucosa in reference to erythematous candidiasis. By contrast, the geographical tongue is characterized by circinate, irregular erythema mainly on the anterior two-thirds of the dorsal and lateral surfaces of the tongue, and the lesion is surrounded by a slightly elevated keratotic band or line. By comparison, changes reflecting vitamin $B_{12}$ deficit may have the nature of diffuse and bright erythema with linear, band-like, or irregular shape on any part of the oral mucosa. On the dorsum of the tongue, it presents as an inflamed area initially and gradually progresses to atrophic mucosa $[17,37]$.

Persistent, intensifying burning of the mouth is often the only symptom that patients complain about [26]. In other cases, pain and/or burning is initially present only on the tip of the tongue but gradually progresses and affects the entire tongue and/or oral cavity [40]. Other symptoms include dry mouth and dysgeusia. Common signs of $B_{12}$ deficiency consist of pale oral mucosa and recurrent oral ulcerations [37]. Additionally, some patients suffer from angular cheilitis (inflammation of the mouth's corners). This condition typically presents with erythema, painful cracking, scaling, bleeding, and ulceration at the corners of the mouth [24]. Atrophy contributes to difficulties in swallowing. Candidiasis of the oral cavity may constitute a secondary complication of the pathology [27]. Moreover, those described changes are accompanied by neurologic abnormalities - reduced or altered sensation and paresthesia [38]. There are reports of hyperpigmentation of the oral mucosa which are accompanied by changes in skin pigmentation [25]. Patients with vitamin $\mathrm{B}_{12}$ deficiency can also be asymptomatic [37].

\section{HEMATOLOGIC SYMPTOMS}

Macrocytic, megaloblastic anemia may develop in the presence of cobalamin deficiency. Macrocytic anemia is manifested by the mean volume of red blood cells (MCV - mean corpuscular volume) exceeding $100 \mu \mathrm{m}^{3}$ / cell. Abnormal red blood cells called macrocytes with a large volume of hemoglobin are formed, which is referred to as macrocytic hyperchromic anemia. Megaloblastic cells are abnormal precursors of red cell lines with improper distribution of chromatin in the nucleus. This is a consequence of disturbances in DNA synthesis [29]. Hypersegmentation of neutrophils appears quite early as a result of depletion of $\mathrm{B}_{12}$ stores $[4,44]$. Polymorphonuclear granulocytes with more than 5 lobes are observed. These changes are accompanied by disorders in the white blood cell production system - giant leukocyte precursors - and the thrombopoietic system - a reduced number of megakaryocytes. Additionally, slight hyperbilirubinemia may appear along with thrombocytopenia, neutropenia or pancytopenia $[4,7]$.

\section{DERMATOLOGICAL SYMPTOMS}

The dermatological manifestation of $\mathrm{B}_{12}$ deficiency is not homogeneous. Symptoms vary by many factors, including race, vascularization of skin and subcutaneous tissue, pigmentation, but also in the general condition of the patient, age, and associated systemic diseases. Skin paleness or hyperpigmentation may be observed. Pale-yellow or gray-yellow, and sometimes lemon skin tone, and occasionally vitiligo foci may appear [7, 25]. These changes are most often seen among patients with dark complexion and they primarily appear on the dorsal surfaces of feet and hands $[25,45]$. The mechanism of this change is likely related to increased synthesis of melanin [31]. Patients report the following symptoms related to their hair condition: excessive hair loss, loss of gloss, brittleness, thinning, fragility, or early graying $[11,35]$.

\section{NEUROLOGICAL SYMPTOMS}

A number of neurological complications arise primarily as a result of the demyelination of the myelin sheath of the spinal cord and cerebral cortex. These include degeneration of the spinal cord, peripheral and optic nerve neuropathy [35]. Some authors suggest that the first and only symptom in the initial phase of $B_{12}$ deficiency is Lhermitte's sign, which is characterized by feeling an electric current passing along the spine when tilting the head forward [17]. Sensory and motor disorders typically occur. They may include numbness, paresthesia of arms and legs, burning pain, loss of the sense of vibration, increased fatigue, muscular hypotonia, and abnormal micturition [19, 39]. There are case reports of weakened or missing stretch reflexes, muscle imbalance and ataxia $[8,19]$. Some authors emphasize that numbness of hands may be the only symptom patients may experience [42].

\section{MENTAL DISORDERS}

Mental disorders, so-called "megaloblastic madness," which are similar to schizophrenia have been observed, as well as cognitive, concentration, memory disorders, dementia, apathy, depression, hallucinations, and psychosis $[21,39,49]$. It is believed that these changes are associated with impaired synthesis of serotonin, norepinephrine, or dopamine. Psychiatric disorders may be the only manifestations of vitamin $B_{12}$ deficiency. 


\section{DIAGNOSIS OF VITAMIN $B_{12}$ DEFICIENCY}

There is no "diagnostic gold standard" to assess $B_{12}$ status [49]. Recognition of the suboptimal $B_{12}$ status begins with the observation of clinical signs from the oral cavity, gastrointestinal and hematologic systems, skin, neurological, or psychiatric symptoms. Several diagnostic tests exist to determine $B_{12}$ status. The serum $B_{12}$ test is one of the most frequently used [34]. However, the concentration of $B_{12}$ in serum that should be considered a deficiency is a matter of debate. While most researchers and clinicians use relatively low concentration (e.g. $<150 \mathrm{pmol} / \mathrm{l})$, others user higher values (e.g. $222 \mathrm{pmol} / \mathrm{l})$. In fact, even higher serum vitamin $\mathrm{B}_{12}$ concentrations were associated with hyperhomocysteinemia (HHcy) and elevated methylmalonic acid (MMA) [40].

Determination of MMA in the serum or urine is used as one of the specific markers of $B_{12}$ status. Elevated MMA indicates $B_{12}$ deficiency. The Institute of Medicine set the normal urine MMA value as 0.58 to $3.56 \mu \mathrm{mol} / \mathrm{mmol}$ creatinine [22]. Different cutoff values for serum MMA have been used, including 210,260, 271, $370 \mathrm{nmol} / \mathrm{l}$, and higher [32].

Hcy is a less specific but also useful marker [33]. HHcy may reflect high methionine intake, a deficiency of $B_{12}$, folic acid or vitamin $B_{6}$. Hcy is also affected by renal function and the use of certain medications including methotrexate and theophylline. The reference value for Hcy is another matter of debate. Some researchers use a concentration of $\geq 15 \mu \mathrm{mol} / \mathrm{l}$ as indicative of HHcy, others $\geq 12 \mu \mathrm{mol} / \mathrm{l}$ and others $\geq 10 \mu \mathrm{mol} / \mathrm{l}[3,5,33]$.

Determination of the level of cobalamin-bound transcobalamin II (holoTC) is a fairly new method of assessing $B_{12}$ status $[3,33]$. It is believed that this test is equally accurate for the assessment of MMA.

The Schilling test is currently rarely used to determine the ability of the body to absorb $\mathrm{B}_{12}$ from the gastrointestinal tract based on the measurement of urinary $\mathrm{B}_{12}$ excretion.

\section{COBALAMIN REPLACEMENT THERAPY}

Treatment of $B_{12}$ deficiency consists of either intramuscular injections or the use of $B_{12}$ supplements. Nasal $B_{12}$ sprays and toothpaste fortified with $B_{12}$ are also available but not nearly as commonly used to treat $B_{12}$ deficiency. The most frequently applied intramuscular injection dose is $1,000 \mu \mathrm{g}$ [43]. Lower doses (e.g. $100 \mu \mathrm{g}$ or $250 \mu \mathrm{g}$ ) are sometimes used to treat children. There is wide variation in the frequency of intramuscular injections, from daily to weekly at the onset of treatment and monthly as follow-up treatment. Monthly injections are used to maintain adequate $B_{12}$ status.

A supplemental $B_{12}$ dose of $1,000 \mu \mathrm{g} /$ day is just as effective as therapy with intramuscular injection [43].
However, when supplements are used, patients would need to use them daily for a longer period of time than when injections are used. Supplemental $B_{12}$ therapy has several advantages and one disadvantage. For example, whereas monthly $B_{12}$ injections wear off, taking daily supplements provides a dose of the vitamin on a consistent basis. Also, the cost of treatment is considerably lower when compared to the intramuscular injection treatments. In addition, a $B_{12}$ tablet can be ingested without supervision of a medical professional. Disadvantages are the lack of standards and lack of control over the quality of supplements.

More than one form of $B_{12}$ are available in intramuscular preparations and as oral supplements. They include at least cyanocobalamin, methylcobalamin, and hydroxocobalamin. All of the above forms of $B_{12}$ have been shown to be effective in treating $B_{12}$ deficiency.

\section{CONCLUSIONS}

$\mathrm{B}_{12}$ deficiency is common and it is manifested in a variety of symptoms. If treatment is not administered in a timely manner, it can lead to progressive deterioration of hematopoietic and nervous systems and affect digestive and absorption processes. Symptoms related to the oral cavity are distinctive and in about half of the cases can help to determine the diagnosis and, consequently, may lead to application of treatment and faster recovery. On the basis of a general health or dental interview and an examination, an attentive practitioner will be able to link the symptoms from other systems with the patient's complaints and clinical signs in the oral mucosa. Considering that a number of adults and elderly have subclinical $\mathrm{B}_{12}$ deficiency, the use of biochemical assessments, such as methylmalonic acid and/or Hcy, during routine checkups could help to identify individuals with suboptimal $\mathrm{B}_{12}$ concentration and treat them before the onset of clinical manifestations.

\section{CONFLICT OF INTEREST}

The authors declare no potential conflicts of interest with respect to the research, authorship, and/or publication of this article.

\section{References}

1. Allen LH. How common is vitamin B12 deficiency? Am J Clin Nutr 2009; 89 (Suppl): 693S-696S.

2. Andres E, Loukili NH, Noel E, et al. Vitamin B12 (cobalamin) deficiency in elderly patients. CMAJ 2004; 171: 251-259.

3. Bożek A, Strojek K, Rokicka D, et al. Niedobór witaminy B12 u chorych przewlekle leczonych metforminą. Świat Med Farm 2012; 11: 12-16 [In Polish].

4. Briani C, Torre CD, Citton V, et al. Cobalamin deficiency: clinical picture and radiological findings. Nutrients 2013; 5: 4521-4539.

5. Carmel R. How I treat cobalamin (vitamin B12) deficiency. Blood 2008; 112: 2214-2221. 
6. Carmel R, Green R, Resenblatt DS, Watkins D. Update on cobalamin, folate, and homocysteine. Hematology Am Hematol Educ Program 2003: 62-81.

7. Chełstowska M, Warzocha K. Clinical symptoms and laboratory changes in differential diagnosis of anemia. Onkologia w Praktyce Klinicznej 2006; 2: 105-116 [In Polish].

8. Crawford JR, Say D. Vitamin B12 deficiency presenting as acute ataxia. BMJ Case Rep 2013; doi: 10.1136/bcr-2013-008840.

9. Cuskelly GJ, Money K, Young IS. Folate and vitamin B12: friendly or enemy nutrients for the elderly. Proc Natur Soc 2007; 66: 548-558.

10. Dali-Youcef N, Andres E. An update on cobalamin deficiency in adults. QJM 2009; 102: 17-28.

11. Demir N, Doğan M, Koç A, et al. Dermatological findings of vitamin B12 deficiency and resolving time of these symptoms. Cutan Ocul Toxicol 2014; 33: 70-73.

12. Derossi SS, Raghavendra S. Anemia. Oral Surg Oral Med Oral Pathol Oral Radiol Endod 2003; 95: 131-141.

13. Dror DK, Allen LH. Effect of vitamin B12 deficiency on neurodevelopment in infants: current knowledge and possible mechanisms. Nutr Rev 2010; 66: 250-255.

14. Drumondt JF, White DK, Damm DD. Megaloblastic anemia with oral lesions: a consequence of gastric bypass surgery. Oral Surg Oral Med Oral Pathol 1985; 59: 149-153.

15. EFSA NDA Panel (EFSA Panel on Dietetic Products, Nutrition and Allergies), 2015. Scientific Opinion on Dietary Reference Values for cobalamin (vitamin B12). EFSA Journal 2015; 13: 4150; doi:10.2903/j.efsa.2015.4150.

16. Field EA, Speechley JA, Rugman FR, Varga E, Tyldesley WR. Ora signs and symptoms in patients with undiagnosed vitamin B12 deficiency. J Oral Pathol Med 1995; 24: 468-470.

17. Graells J, Ojeda RM, Muniesa C, Gonzalez J, Saavedra J. Glossitis with linear lesions: an early sign of vitamin B12 deficiency. J Am Acad Dermatol 2009; 60: 498-500.

18. Greenberg MS. Clinical and histologic changes of the oral mucosa in pernicious anemia. Oral Surg Oral Med Oral Pathol 1981; 52: 38-42.

19. Gröber U, Kisters K, Schmidt J. Neuroenhancement with vitamin B12-underestimated neurological significance. Nutrients 2013; 5 5031-5045.

20. Herbert V. Vitamin B-12: plant sources, requirements, and assay. Am J Clin Nutr 1988; 48: 852-858.

21. Hutto BR. Folate and cobalamin in psychiatric illness. Compr Psychiatry 1997; 38: 305-314.

22. Institute of Medicine. Dietary Reference Intakes for Thiamin, Riboflavin, Niacin, Vitamin B6, Folate, Vitamin B12, Pantothenic Acid Biotin, and Choline. http://www.iom.edu/Reports/2000/Dietary-Reference-Intakes-for-Thiamin-Riboflavin-Niacin-Vitamin-B6-Folate-Vitamin-B12-Pantothenic-Acid-Biotin-and-Choline.aspx.

23. Jarosz M, Dzieniszewski J, Rychlik E. Stan odżywienia chorych przyjmowanych do i wypisywanych ze szpitali w Polsce. In: Jarosz M (ed.). Zasady prawidłowego żywienia chorych w szpitalach. Warszawa, Instytut Żywności i Żywienia 2011; 15-25 [In Polish].

24. Jihoon K, Moon-Jong K, Hong-Seop K. Oral manifestations in vitamin $\mathrm{B}_{12}$ deficiency patients with or without history of gastrectomy. BMC Oral Health 2016; 16: 60.

25. Kannan R, Joo Ming Ng M. Cutaneous lesions and vitamin B12 deficiency. Can Fam Physician 2008; 54: 529-532.

26. Kośmider A, Czaczyk K. Vitamin B12 - structure, biosynthesis, functions, and methods of determination. Żywność Nauka Technologia Jakość 2010; 5: 17-32 [In Polish].

27. Koury MJ, Ponka P. New insights into erythropoiesis: the roles of folate, vitamin B12, and iron. Annu Rev Nutr 2004; 24: 105-131.

28. Loikas S. Vitamin B12 deficiency in the aged: a population-based study. Age Ageing 2007; 36: 177-183.

29. Lu SY, Wu HC. Initial diagnosis of anemia from sore mouth and improved classification of anemia by MCV and RDW in 30 patients. Ora Surg Oral Med Oral Pathol Oral Radiol Endod 2004; 98: 679-685.

30. Miller JW. Vitamin B12 deficiency, tumor necrosis factor-alpha, and epidermal growth factor: a novel function for vitamin B12? Nutr Rev 2002; 60 (5 Pt 1): 142-144.
31. Mori K, Ando I, Kukita A. Generalized hyperpigmentation of the skin due to vitamin B12 deficiency. J Dermatol 2001; 28: 282-285.

32. Pawlak R, Parrott SJ, Raj S, Cullum-Dugan D, Lucus D. How prevalent is vitamin B12 among vegetarians? Nutr Rev 2013; 71: 110-117.

33. Pawlak R. Vitamin B12 for diabetes patients treated with metformin. J Fam Med Dis Prev 2017; 3: 057; DOI: 10.23937/24695793/1510057.

34. Pawlak R, James PS, Raj S, Collum-Drugan D, Lucas D. Understanding vitamin B12. Am J Lifestyle Med 2012; 7: 59-65.

35. Pawlak R. Vitamin B12. Combating the epidemic of deficiency. $1^{\text {st }}$ edition. Greenville, NC 2016.

36. Pineles SL, Avery RA, Liu GT. Vitamin B12 optic neuropathy in autism. Pediatrics 2010; 126: 967-970.

37. Pontes HA, Neto NC, Ferreira KB, et al. Oral manifestations of vitamin B12 deficiency: a case report. J Can Dent Assoc 2009; 75 533-537.

38. Rathod R, Khaire A, Kale A, Joshi S. A combined supplementation of vitamin $B_{12}$ and $n-3$ polyunsaturated fatty acids across two generations improves nerve growth factor and vascular endothelial growth factor levels in the rat hippocampus. Neuroscience 2016; 339: 376-384.

39. Rusher DR, Pawlak R. A review of 89 published case studies of vitamin B12 deficiency. J Human Nutr Food Science 2013; 1: 1008.

40. Scalabrino G, Corsi MM, Veber D, et al. Cobalamin (vitamin $\mathrm{B}(12))$ positively regulates interleukin-6 levels in rat cerebrospinal fluid. J Neuroimmunol 2002; 127: 37-43.

41. Smith AD, Refsum H. Do we need to reconsider the desirable blood level of vitamin B12? J Intern Med 2012; 271: 179-182.

42. Stabler SP, Allen RH, Savage DG, Lindenbaum J. Clinical spectrum and diagnosis of cobalamin deficiency. Blood 1990; 76: 871-881.

43. Stabler SP. Vitamin B12 deficiency. New Engl J Med 2013; 368: 149-160.

44. Thompson WG, Cassino C, Babitz L, et al. Hypersegmented neutrophils and vitamin $B_{12}$ deficiency. Acta Haematol 1989; 81: 186-191.

45. Van Asselt DZ, Blom HJ, Zuiterent R, et al. Clinical significance of low cobalamin levels in older hospital patients. Neth J Med 2000; 57: 41-49.

46. Watanabe F. Vitamin B12 sources and bioavailability. Exp Biol Med 2007; 232: 1266-1274.

47. Zabrocka J, Wojszel ZB. Niedobór witaminy B12 w wieku podeszłym - przyczyny, następstwa, podejście terapeutyczne. Geriatria 2013; 7: 24-32 [In Polish].

48. Zboch M, Gwizdak-Sikowska B, Serafin J, Śmigórski K, Tyfel P, Leszek J. Deficit of vitamin B12 as a factor affecting development of the dementive process. Medycyna Rodzinna 2010; 1: 14-19 [In Polish].

49. Zhou P, Hua H, Yan Z, Zheng L, Liu X. Diagnostic value of oral "beefy red" patch in vitamin B12 deficiency. Ther Clin Risk Manag 2018; 14: 1391-1397.

50. Zubowska M, Zalewska-Szewczyk B, Stengerd W, Mycko K, Młynarski W. Severe vitamin B12 deficiency of unknown origin in 10-months-old girl. Hematologia 2011; 2: 111-118 [In Polish].

51. Xia W, Chen W, Peng WF, Li KT. Industrial vitamin B12 production by Pseudomonas denitrificans using maltose syrup and corn steep liquor as the cost-effective fermentation substrates. Bioprocess Biosyst Eng 2015; 38: 1065-1073.

52. Yakut M, Ustün Y, Kabacam G, Soykan I. Serum vitamin B12 and folate status in patients with inflammatory bowel diseases. Eur J Med 2010; 21: 320-323. 